\title{
Marine and Soil Derived Natural Products: A New Source of Novel Cardiovascular Protective Agents Targeting the Endothelin System
}

Authors

Affiliations
Nadir Planes $^{1,2}$, Catherina Caballero-George ${ }^{1}$

${ }^{1}$ Institute for Scientific Research and High Technology Services, City of Knowledge, Clayton, Panama, Republic of Panama

2 Department of Biotechnology, Acharya Nagarjuna University, Guntur, India
Key words

- endothelin

- hypertension

- cardiovascular

- marine natural products

- microorganisms

- ecology received revised

August 3, 2014

accepted

Bibliography

DOI http://dx.doi.org/

10.1055/s-0034-1396205

Published online February 5 ,

2015

Planta Med 2015; 81: 630-636

(c) Georg Thieme Verlag KG

Stuttgart · New York .

ISSN 0032-0943

\section{Correspondence}

\section{Dr. Catherina Caballero-}

\section{George}

Institute for Scientific Research and High Technology Services

Building 219, City of Knowledge

Clayton, Panama

Republic of Panama

Phone: + 5075170737

Fax: + $5075070020 / 5170701$

c.caballerogeorge@gmail.com

\section{Abstract \\ $\nabla$}

Inhibition of the endothelin system is a recognized therapeutic approach for treating complex cardiovascular diseases. The search for natural inhibitors of the endothelin system has focused mainly on land, with recent, emerging data sug-

\section{Introduction}

$\nabla$

More than three decades of research on marine natural products have exposed their potential as antimicrobial, antiviral, antiparasitic, anticancer, anti-inflammatory, neuroprotective, and immunomodulatory agents [1-6]. However, very little is known about their cardioprotective potential $[5,6]$. Cardiovascular disorders remain the main cause of mortality, morbidity, and health care burden worldwide [7]. The endothelin system is a key player in many conditions associated with cardiovascular disorders including hypertension, heart failure [7-9], and atherosclerosis [10]. The current literature regarding the screening of marine natural products for cardioprotection focuses on well validated targets such as the angiotensin converting enzyme of renin-angiotensin-aldosteron [11] and the endothelin receptors [12-15]. The emerging data suggest that marine microorganisms are a suitable source of bioactive lead compounds. In this review, we focus on marine natural products targeting the inhibition of the endothelin system, their origin, their mechanism of action, and their ecological relevance. Other marine natural products with cardiovascular activity will also be briefly discussed. gesting the underestimated potential of marine microorganisms for producing leads with cardioprotective potential. The present work reviews natural products identified as inhibitors of the endothelin system, their origin, their mechanism of action, and their ecological significance. 


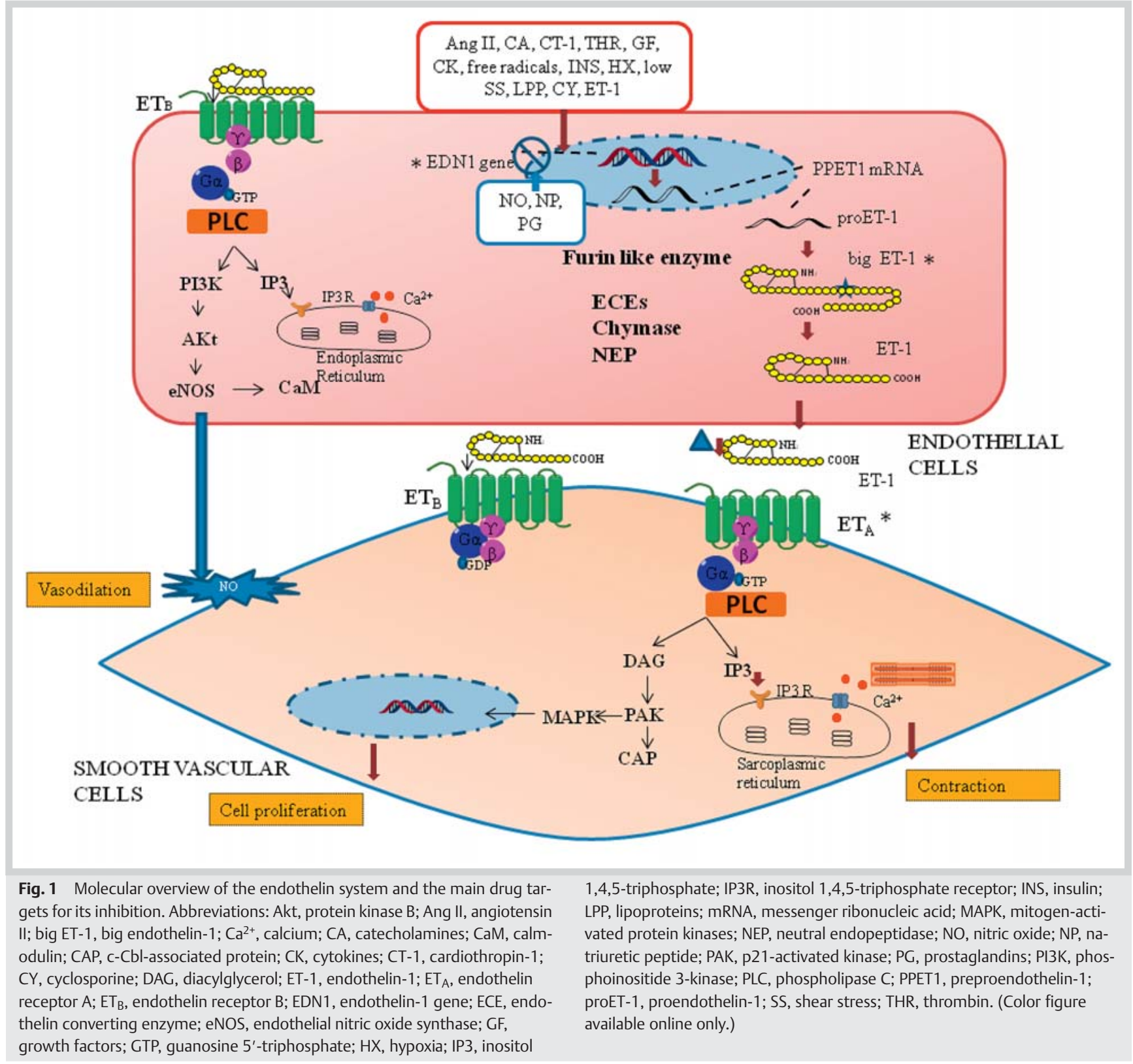

receptors [20]. When ET-1 interacts with the $\mathrm{ET}_{\mathrm{A}}$ receptor, a G protein hydrolyzes phospholipase $\mathrm{C}$ to form diacylglycerol (DAG) and inositol 1,4,5-triphosphate (IP3). IP3 increases cytoplasmic calcium $\left(\mathrm{Ca}^{2+}\right)$ throuth activation of its receptors and transmembrane $\mathrm{Ca}^{2+}$ channels located on the endoplasmic reticulum resulting in vasoconstriction ( Fig. 1) [22]. DAG can also lead to activation of proto-oncogenes including those involved in the MAPK cascade [22].

Stimulation of $\mathrm{ET}_{\mathrm{B}}$ receptors leads to activation of phosphoinositide 3-kinase (PI3K) and downstream activation of protein B kinase/Akt. The PI3K/Akt pathway is responsible for activation of endothelial nitric oxide synthase (eNOS), where nitric oxide (NO) antagonizes ET-1 synthesis via inhibition of PPET1 transcription. $\mathrm{ET}_{\mathrm{B}}$ receptors mediate the release of other vasodilators like prostaglandins and the endothelium-derived hyperpolarizing factor [23].

The deleterious effects of ET-1 can be prevented by different mechanisms. They include suppression of the expression of
EDN1, translation of proET-1, and activation of ECE and endothelin receptors $[24,25]$.

\section{Endothelin-1 gene inhibitors}

There is a specific gene that encodes for each precursor of the mature isoforms of the endothelin family [21]. These genes are susceptible to inhibition by diverse factors. For instance, EDN1 expression may be inhibited by endothelium-derived NO, nitrovasodilators, natriuretic peptides, heparin, and prostaglandins ( Fig. 1) [20,21], as well as high shear stress [26].

\section{Endothelin converting enzyme, neutral endopeptidase} and chymase inhibitors

Among the metalloproteases that may cleave big ET-1 to produce ET-1 are pepsin, cathepsin D, and thiol proteases [26], which are sensitive to inhibition by phosphoramidon [27]. Another ECE inhibitor is R568 [28], a calcimimetic substance that induces changes in the synthesis of endothelial vasoactive factors. In addi- 
tion, NEP is an important enzymatic target which may be inhibited by both phosphoramidon and thiorphon. The combination of $\mathrm{NEP} / \mathrm{ECE}$ inhibition, as in SLV 306 (daglutril), is a recent approach to reduce adverse effects produced by NEP inhibition [29].

\section{Endothelin receptor antagonists}

Effective antagonism of endothelin receptors has been achieved by compounds like bosentan (non-selective $\mathrm{ET}_{\mathrm{A}} / \mathrm{ET}_{\mathrm{B}}$ ), BQ-123 (selective $\mathrm{ET}_{\mathrm{A}}$ ), $\mathrm{BQ}-788$ (selective $\mathrm{ET}_{\mathrm{B}}$ ) $[24,30]$, sitaxentan (selective $\mathrm{ET}_{\mathrm{A}}$ ), atrasentan (selective $\mathrm{ET}_{\mathrm{A}}$ ), ambrisentan (selective $\mathrm{ET}_{\mathrm{A}}$ ), and darusentam (selective $\mathrm{ET}_{\mathrm{A}}$ ) [24]. Selective antagonism of the $\mathrm{ET}_{\mathrm{A}}$ receptor has been effective for treating pulmonary arterial hypertension [24]. Potential underlying mechanisms include reducing pulmonary artery pressure, inhibiting vascular remodeling, improving exercise capacity and pulmonary haemodynamics, and reducing the Borg dyspnea index [21].

Although non-selective $\mathrm{ET}_{\mathrm{A}} / \mathrm{ET}_{\mathrm{B}}$ receptor antagonism effectively decreases blood pressure, it causes vasoconstriction by blockade of tonic endothelial $\mathrm{ET}_{\mathrm{B}}$-receptor-mediated stimulation of NO and prostacyclin generation and affects the clearance of circulating ET-1 ( Fig. 1) [24]. Thus, the selection between selective and non-selective antagonism of endothelin receptors depends on the individual patient response.

\section{Marine Natural Products as Inhibitors of the Endothelin System \\ $\nabla$}

A number of marine natural products of diverse chemical structures have been found to possess cardiovascular activities. These include small peptides produced by enzymatic hydrolisis of marine proteins, chitosan derivatives, and phlorotanins which inhibit the angiotensin converting enzyme [11]; xestoquinone ( Fig. 2, 1), a pentacyclic quinone with inotropic activity and capacity to inhibit Na/K-ATPase [31] obtained from Xestospongia sapra; D-polymannuronic sulfate ( Fig. 2, 2) obtained from brown algae that increase NO and decrease plasma levels of Ang II and ET-1 [32]; and xestospongin C ( $\odot$ Fig. 2, 3) an alkaloid from Xestospongia exigua, spongosine ( Fig. 2,4 ) a nucleoside from Cryptotethia crypta [34], 12-epi-scalaradial ( $\odot$ Fig. 2, 5) a sesterpene from Hyrtios erecta [33], and eledoisin ( $\bullet$ Fig. 2, 6), a peptide from Eledone sp. [35] with hypotensive activity.

The majority of natural products capable of inhibiting the endothelin system have been obtained from microorganisms and plants of terrestrial origin. Since the discovery of the cyclic pentapeptide BE-18257B ( Fig. 2, 7) in the bacteria Streptomyces misakiensis [36], which originated the first selective endothelin $\mathrm{ET}_{\mathrm{A}}$ receptor antagonist BQ-123 [37], more attention has been given to finding endothelin antagonists within microorganisms.

\section{Bacteria}

Following the discovery of BE-18257B, two more binding inhibitors of endothelin receptors were identified in soil-born Streptomyces, i.e., the benzo[ $\alpha]$ anthraquinones WS009 A and B ( $\odot$ Fig. 2, 8-9) ( Table 1) [38]. Blastorbacter sp. has been the one bacteria obtained from sea water, from which the non-peptide metalloprotease inhibitor B90063 ( Fig. 2, 10) has been obtained [39]. B90063 inhibits both ECE and NEP, preventing the generation of ET-1 ( Table 1). Other inhibitors of ECE were the benzo[ $\alpha]$ naphthacene quinones WS79089 A, B, and C ( Fig. 2, 11-13) ( Table 1) obtained from the soil-born Streptosporangium roseum 79089 (० Fig. 2) [40].
Fungi

An interesting fact is that compounds obtained from soil-born fungi, which exhibited endothelin receptor binding capacity, were also found in fungi from marine habitats. This is the case of the spirocyclic drimanes stachybocin A and B (- Fig. 2, 14-15) isolated from Stachybotrys sp. M6222 found in soil [41] and Stachybotrys sp. MF347 found in driftwood [42]. Drimane sesquiterpenoids have been commonly isolated from marine-derived fungi specially those associated with mangrove [43] and sponges [44]. Dimeric spirodihydrobenzofuranlactam compounds [41, $45]$ and those with the sesquiterpene drimane skeleton $[46,47]$ ( Fig. 2, 17-23) inhibited the binding of [ ${ }^{125}$ I]ET-1 to both endothelin receptors, with a consistent preference for the $\mathrm{ET}_{\mathrm{B}}$ receptor (- Table 1 ).

Azaphilones are another group of fungal metabolites found to be produced in fresh [13] and sea water [48-50]. In contrast to the above mentioned drimanes, the group of bioactive azaphilones found in Penicillium sclerotirum X11853 inhibited the binding of [ $\left.{ }^{125} \mathrm{I}\right] \mathrm{ET}-1$ to both endothelin receptors, with a consistent preference for the $\mathrm{ET}_{\mathrm{A}}$ receptor ( Fig. 2, 24-29) ( Table 1) [13].

Other compounds like diphenyl ether RES-1214-1 and -2 ( Fig. 2, 30-31) obtained from soil-born Pestalotiopsis sp. also inhibited the binding of [125I]ET-1 to the $\mathrm{ET}_{\mathrm{A}}$ receptor [51].

\section{Porifera}

Although marine invertebrates, especially sponges, have been claimed as the largest source of chemically diverse marine natural products [52], it is intriguing why information on cardiovascular activity of compounds obtained from sponges is scarce. The literature shows that two compounds obtained from sponges have been identified as inhibitors of the endothelin systems. The first is 34-sulfatobastadin 13 ( Fig. 2, 32), a bromotyrosine derivative which inhibited the binding of $\left[{ }^{125} \mathrm{ET}-1\right]$ to the $\mathrm{ET}_{\mathrm{A}}$ receptor [12], and the second is the novel sterol sulfate halistanol disulfate B ( Fig. 2, 33) that inhibited ECE ( Table 1) [53].

\section{Ecological Significance of Natural Inhibitors of the Endothelin System \\ $\nabla$}

The majority of the active natural products found within this group are drimane sesquiterpenes. Terpenes have been thought to play a critical role in antagonistic or mutualistic interactions among organisms. They are associated with defense mechanisms in terrestrial as well as in marine environments. In both habitats, molecules with deterrent and antimicrobial activity are the typical chemical defenses of sedentary, slow-moving, or otherwise poorly defended organisms [54].

Drimane sesquiterpenes are potent antimicrobials and believed to deter feeding on plants and sponges by acting directly on taste receptors [54]. Interestingly, taste receptors belong to the GPCR family as so the endothelin receptors $[55,56]$. Thus, it is possible that drimanes are non-selective GPCR ligands, which might explain their ability to bind $\mathrm{ET}_{\mathrm{A}}$ and $\mathrm{ET}_{\mathrm{B}}$. The microorganisms reviewed in this work, which produce these sesquiterpenes, are frequently present in association with sponges, corals, and algae, thus validating their ecological significance in the marine ecosystem.

The significance of sulfated polysaccharides as the vasoactive $D$ polymannuronic sulfate ( Fig. 2) [32] in the marine environment is not completely understood. Sulfated polysaccharides are known to be largely species-specific and involved in cell matrix 


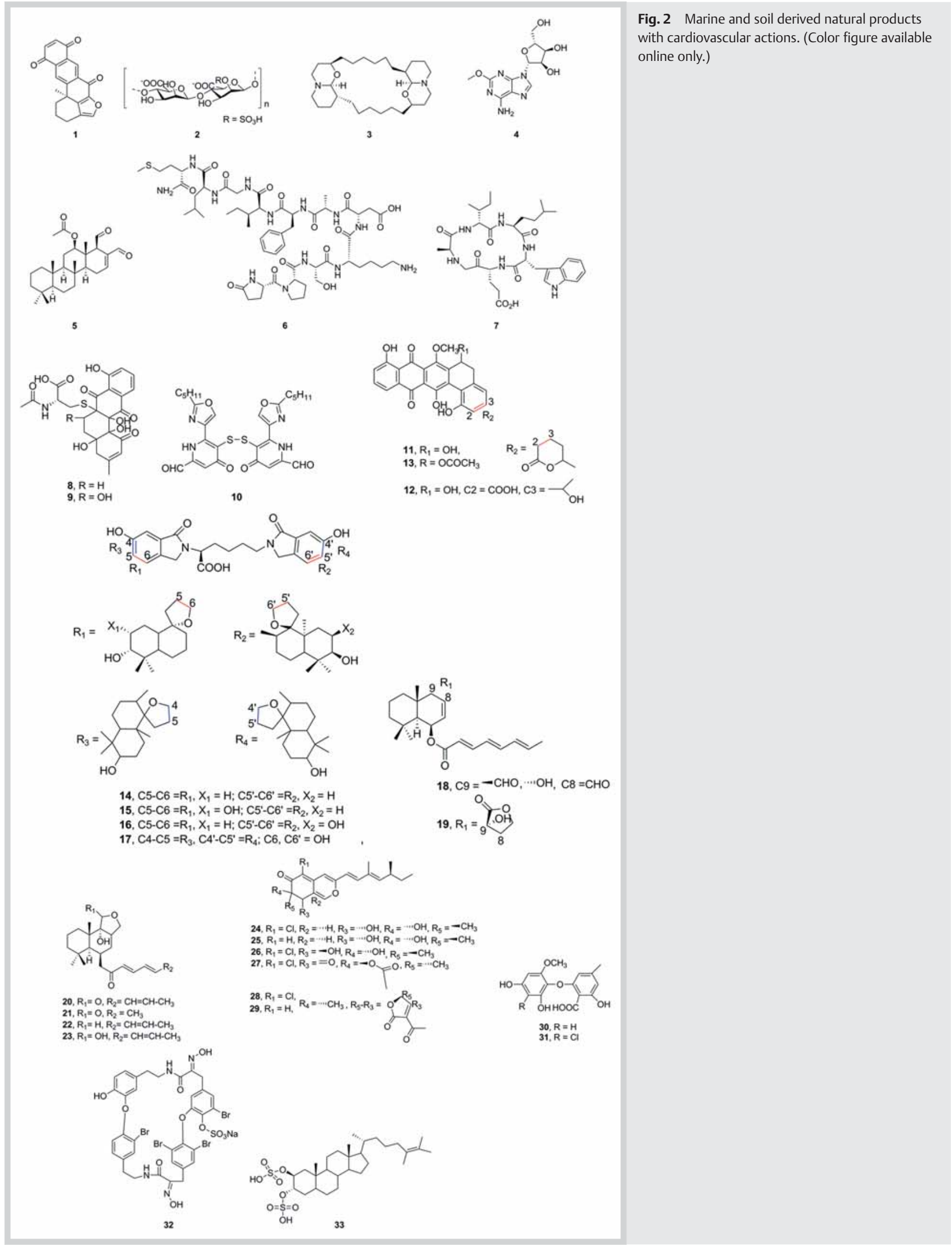

interactions, cell signaling and development [57]. They represent an enormous source of different chemical structures with the advantage of a lower risk to patients [57].
Additionally, peptides are another group of compounds from microbes and sponges that act on the endothelin system. These sub- 
Table 1 Natural products from microorganisms and marine sponges acting as inhibitors of the endothelin system.

\begin{tabular}{|c|c|c|c|c|c|c|c|c|}
\hline Compound & $\begin{array}{l}\text { Number of } \\
\text { structure }\end{array}$ & Chemistry & ORGa & Species & Origin & MMOA $^{b}$ & $\mathrm{IC}_{50}(\mu \mathrm{M})$ & Ref. \\
\hline BE-18257B & 7 & $\begin{array}{l}\text { cyclic penta- } \\
\text { peptide }\end{array}$ & $\mathrm{BA}$ & $\begin{array}{l}\text { Streptomyces misa- } \\
\text { kienses }\end{array}$ & Soil & $\mathrm{ET}_{\mathrm{A}}$ & 3.0 & [36] \\
\hline W5009 A & 8 & $\begin{array}{l}\text { benz[a]anthra- } \\
\text { quinone }\end{array}$ & $\mathrm{BA}$ & $\begin{array}{l}\text { Streptomyces sp. } \\
89009\end{array}$ & Soil & ETs & 5.8 & [38] \\
\hline W5009 B & 9 & $\begin{array}{l}\text { benz[a]anthra- } \\
\text { quinone }\end{array}$ & $\mathrm{BA}$ & $\begin{array}{l}\text { Streptomyces sp. } \\
89009\end{array}$ & Soil & ETs & 67.0 & [41] \\
\hline B-90063 & 10 & pyridone & $\mathrm{BA}$ & $\begin{array}{l}\text { Blastobacter sp. SANK } \\
71894\end{array}$ & Sea water & ECE/NEP. & $1.0 / 66.0$ & [39] \\
\hline WS79089 A & 11 & $\begin{array}{l}\text { benzo[ } \alpha] \text { naph- } \\
\text { tacen quinone }\end{array}$ & EU & $\begin{array}{l}\text { Streptosporangium } \\
\text { roseum } 79089\end{array}$ & Soil & ECE & 0.7 & [40] \\
\hline WS79089 B & 12 & $\begin{array}{l}\text { benzo[ } \alpha] \text { naph- } \\
\text { tacen quinone }\end{array}$ & EU & $\begin{array}{l}\text { Streptosporangium } \\
\text { roseum } 79089\end{array}$ & Soil & ECE & 0.1 & [40] \\
\hline WS79089C & 13 & $\begin{array}{l}\text { benzo[ } \alpha] \text { naph- } \\
\text { tacen quinone }\end{array}$ & EU & $\begin{array}{l}\text { Streptosporangium } \\
\text { roseum } 79089\end{array}$ & Soil/ & ECE & 3.4 & [40] \\
\hline Stachybocin A & 14 & $\begin{array}{l}\text { drimane ses- } \\
\text { quiterpene }\end{array}$ & FU & $\begin{array}{l}\text { Stachybotrys sp. M } \\
6222\end{array}$ & Soil & $\mathrm{ET}_{\mathrm{A}} / \mathrm{ET}_{\mathrm{B}}$ & $13.0 / 7.9$ & [41] \\
\hline Stachybocin B & 15 & $\begin{array}{l}\text { drimane ses- } \\
\text { quiterpene }\end{array}$ & FU & $\begin{array}{l}\text { Stachybotrys sp. M } \\
6222\end{array}$ & Soil & $\mathrm{ET}_{\mathrm{A}} / \mathrm{ET}_{\mathrm{B}}$ & $12.0 / 9.5$ & [41] \\
\hline Stachybocin C & 16 & $\begin{array}{l}\text { drimane ses- } \\
\text { quiterpene }\end{array}$ & FU & $\begin{array}{l}\text { Stachybotrys sp. M } \\
6222\end{array}$ & Soil & $\mathrm{ET}_{\mathrm{A}} / \mathrm{ET}_{\mathrm{B}}$ & $15.0 / 9.4$ & [41] \\
\hline $\begin{array}{l}\text { Spirodihydro-ben- } \\
\text { zofuranlactam VI }\end{array}$ & 17 & $\begin{array}{l}\text { drimane ses- } \\
\text { quiterpene }\end{array}$ & FU & $\begin{array}{l}\text { Stachybotrys charta- } \\
\text { rum }\end{array}$ & Soil & $\mathrm{ET}_{\mathrm{A}}$ & 1.5 & [45] \\
\hline RES-1149-1 & 18 & $\begin{array}{l}\text { drimane ses- } \\
\text { quiterpene }\end{array}$ & FU & $\begin{array}{l}\text { Aspergillus sp. RE- } \\
1149\end{array}$ & UNC & $\mathrm{ET}_{\mathrm{A}} / \mathrm{ET}_{\mathrm{B}}$ & $25.8 / 1.6$ & [46] \\
\hline RES-1149-2 & 19 & $\begin{array}{l}\text { drimane ses- } \\
\text { quiterpene }\end{array}$ & FU & $\begin{array}{l}\text { Aspergillus sp. RE- } \\
1149\end{array}$ & Soil & $\mathrm{ET}_{\mathrm{B}}$ & 20.0 & [46] \\
\hline Drimane 1 & 20 & $\begin{array}{l}\text { drimane ses- } \\
\text { quiterpene }\end{array}$ & FU & $\begin{array}{l}\text { Aspergillus ustus var. } \\
\text { pseudodeflectus } \\
\text { X3811 }\end{array}$ & Desert soil & $\mathrm{ET}_{\mathrm{A}} / \mathrm{ET}_{\mathrm{B}}$ & $155.0 / 50$ & [47] \\
\hline Drimane 2 & 21 & $\begin{array}{l}\text { drimane ses- } \\
\text { quiterpene }\end{array}$ & FU & $\begin{array}{l}\text { Aspergillus ustus var. } \\
\text { pseudodeflectus } \\
\text { X3811 }\end{array}$ & Desert soil & $\mathrm{ET}_{\mathrm{A}} / \mathrm{ET}_{\mathrm{B}}$ & $80.0 / 55.0$ & [47] \\
\hline Drimane 3 & 22 & $\begin{array}{l}\text { drimane ses- } \\
\text { quiterpene }\end{array}$ & FU & $\begin{array}{l}\text { Aspergillus ustus var. } \\
\text { pseudodeflectus } \\
\text { X3811 }\end{array}$ & Desert soil & $\mathrm{ET}_{\mathrm{A}} / \mathrm{ET}_{\mathrm{B}}$ & $65.0 / 21.0$ & [47] \\
\hline Drimane 5 & 23 & $\begin{array}{l}\text { drimane ses- } \\
\text { quiterpene }\end{array}$ & FU & $\begin{array}{l}\text { Aspergillus ustus var. } \\
\text { pseudodeflectus } \\
\text { X3811 }\end{array}$ & Desert soil & $\mathrm{ET}_{\mathrm{A}} / \mathrm{ET}_{\mathrm{B}}$ & $50.0 / 70.0$ & [47] \\
\hline $\begin{array}{l}\text { Isochromophilone } \\
\text { III }\end{array}$ & 24 & azaphilones & FU & $\begin{array}{l}\text { Penicillium sclerotio- } \\
\text { rum X11853 }\end{array}$ & $\begin{array}{l}\text { Tropical for- } \\
\text { est stream }\end{array}$ & $\mathrm{ET}_{\mathrm{A}} / \mathrm{ET}_{\mathrm{B}}$ & $9.0 / 77.0$ & [13] \\
\hline $\begin{array}{l}\text { Isochromophilone } \\
\text { III dechloro ana- } \\
\text { logue }\end{array}$ & 25 & azaphilones & FU & $\begin{array}{l}\text { Penicillium sclerotio- } \\
\text { rum X11853 }\end{array}$ & $\begin{array}{l}\text { Tropical for- } \\
\text { est stream }\end{array}$ & $\mathrm{ET}_{\mathrm{A}} / \mathrm{ET}_{\mathrm{B}}$ & $28.0 / 172.0$ & [13] \\
\hline $\begin{array}{l}\text { (8R)-7-deacetyl- } \\
O^{8}, 8 \text {-dihydro-7-epi- } \\
\text { sclerotiorin }\end{array}$ & 26 & azaphilones & FU & $\begin{array}{l}\text { Penicillium sclerotio- } \\
\text { rum X11853 }\end{array}$ & $\begin{array}{l}\text { Tropical for- } \\
\text { est stream }\end{array}$ & $\begin{array}{l}\mathrm{ET}_{\mathrm{A}} / \mathrm{ET}_{\mathrm{B}} \\
\mathrm{ARA}\end{array}$ & $\begin{array}{l}5.0 / 50.0 \\
33.0\end{array}$ & [13] \\
\hline$(+)$-sclerotiorin & 27 & azaphilones & FU & $\begin{array}{l}\text { Penicillium sclerotio- } \\
\text { rum X11853 }\end{array}$ & $\begin{array}{l}\text { Tropical for- } \\
\text { est stream }\end{array}$ & $\mathrm{ET}_{\mathrm{A}} / \mathrm{ET}_{\mathrm{B}}$ & $75.0 / 12.0$ & [13] \\
\hline 5-chloroisorotiorin & 28 & azaphilones & FU & $\begin{array}{l}\text { Penicillium sclerotio- } \\
\text { rum X11853 }\end{array}$ & $\begin{array}{l}\text { Tropical for- } \\
\text { est stream }\end{array}$ & $\mathrm{ET}_{\mathrm{A}} / \mathrm{ET}_{\mathrm{B}}$ & $35.0 / 8.0$ & [13] \\
\hline Ochrephilone & 29 & azaphilones & FU & $\begin{array}{l}\text { Penicillium sclerotio- } \\
\text { rum X11853 }\end{array}$ & $\begin{array}{l}\text { Tropical for- } \\
\text { est stream }\end{array}$ & $\mathrm{ET}_{\mathrm{A}} / \mathrm{ET}_{\mathrm{B}}$ & $26.0 / 85.0$ & [13] \\
\hline RES-1214-1 & 30 & diphenyl ether & FU & Pestalotiopsis sp. & Soil & $\mathrm{ET}_{\mathrm{A}}$ & 14.9 & [51] \\
\hline RES-1214-2 & 31 & diphenyl ether & FU & Pestalotiopsis sp. & Soil & $\mathrm{ET}_{\mathrm{A}}$ & 49.7 & [51] \\
\hline $\begin{array}{l}\text { 34-Sulfatobastadin } \\
13\end{array}$ & 32 & bromotyrosine & $\mathrm{PO}$ & lanthella sp. & $\begin{array}{l}\text { Sandy-rubble } \\
\text { reef }\end{array}$ & $\mathrm{ET}_{\mathrm{A}}$ & 39.0 & [12] \\
\hline $\begin{array}{l}\text { Halistanol disulfate } \\
\text { B }\end{array}$ & 33 & sulfated sterol & $\mathrm{PO}$ & Pachastrella sp. & $\begin{array}{l}\text { Marine rocky } \\
\text { substrate }\end{array}$ & ECE & 2.1 & [53] \\
\hline
\end{tabular}

a ORG: type of organism. BA: Bacteria; EU: Eubacteria; FU: Fungi; PO: Porifera. ${ }^{\mathrm{b}} \mathrm{MMOA}$ : molecular mechanism of action. $\mathrm{ET}_{\mathrm{A} / \mathrm{ET}}$ : receptor binding inhibition of [25I]ET-1; ETs: undetermined endothelin receptors; ECE: inhibition of endothelin converting enzyme; NEP: inhibition of neutral endopeptidase; ARA: receptor mediated arachidonic acid release. cUN: undetermined 
stances are believed to belong to their classical chemical defense machinery $[58,59]$.

\section{Discussion}

Microorganisms are a major source for new drugs with more than 50000 microbial natural products playing an important role in drug discovery [60]. The majority of these have been isolated from terrestrial-borne microbes [60], possibly because they were more readily available when compared to marine microbes. The available literature shows that the search for natural inhibitors of the endothelin system has been done mainly in land, yielding a wide variety of chemical compounds. Even though this search produces a biased sampling, it is exciting to note that the results accentuate the underestimated potential of microorganisms for producing leads with cardioprotective potential.

While the question may rise whether the inhibitory activities found for the compounds described in this review are of therapeutic relevance or not, it is worth mentioning that lead compounds may have considerably low activities ( $\mathrm{IC}_{50}$ values in the micromolar range) and still hold the potential to become very potent drugs after few modifications. For example, the selective $\mathrm{ET}_{\mathrm{A}}$ receptor antagonist $\mathrm{BQ} 123\left(\mathrm{IC}_{50}=7.3 \mathrm{nM}\right)$ [37], is a semisynthetic product obtained from the natural product BE-18257B $\left(\mathrm{IC}_{50}=3.0 \mu \mathrm{M}\right)(\odot$ Table $\mathbf{1})$.

Oceans encompass a stressful and competitive habitat with unique conditions of $\mathrm{pH}$, temperature, pressure, oxygen, light, nutrients, and salinity, all of which force organisms to adapt both chemically and physiologically to survive in it $[1,40]$. The corresponding modifications in gene regulation and metabolic pathways increase the chances of finding unique and complex natural products that differ from organisms living in terrestrial habitats $[1,40]$.

The large display of novel and complex chemical structures found in marine natural products as well as the extension of their therapeutic applications, support the marine environment as a promising source of new drugs. The increasing number of bioactive natural products from marine-derived fungi presents a great challenge and sets high expectations in finding, in these groups of organisms, new leads for the protection of the cardiovascular system.

\section{Acknowledgements \\ $\nabla$}

The authors gratefully acknowledge the National Secretariat for Science, Technology and Innovation (SENACYT) of the Republic of Panama for financial support through the incentive program of the National Innovation System (SNI) as well as through grants COL08-014 and COL10-070. Thanks are also due to IFARHU from the Panamanian government, which jointly with SENACYT awarded a scholarship to Ms. Nadir Planes.

\section{Conflict of Interest}

$\nabla$

The authors declare no conflict of interest.

\section{References}

1 Skropeta $D$, Wei $L$. Recent advances in deep-sea natural products. Nat Prod Rep 2014; 31: 999-1025
2 Blunt JW, Copp BR, Keyzers RA, Munro MH, Prinsep MR. Marine natural products. Nat Prod Rep 2014; 31: 160-258

3 Abad MJ, Bedoya LM, Bermejo P. Natural marine anti-inflammatory products. Mini Rev Med Chem 2008; 8: 740-754

4 König $G$, Wright $A D$. Marine natural products research: current directions and future potential. Planta Med 1996; 62: 193-211

5 Mayer AM, Hamann MT. Marine pharmacology in 1999: compounds with antibacterial, anticoagulant, antifungal, anthelmintic, anti-inflammatory, antiplatelet, antiprotozoal and antiviral activities affecting the cardiovascular, endocrine, immune and nervous systems, and other miscellaneous mechanisms of action. Comp Biochem Physiol C Toxicol Pharmacol 2002; 132: 315-339

6 Mayer AM, Rodríguez AD, Taglialatela-Scafati O, Fusetani N. Marine pharmacology in 2009-2011: marine compounds with antibacterial, antidiabetic, antifungal, anti-inflammatory, antiprotozoal, antituberculosis, and antiviral activities; affecting the immune and nervous systems, and other miscellaneous mechanisms of action. Mar Drugs 2013; 1: $2510-2573$

7 von Lueder TG, Atar D, Krum H. Current role of neprilysin inhibitors in hypertension and heart failure. Pharmacol Ther 2014; 144: 41-49

8 Nasser SA, El-Mas MM. Endothelin $\mathrm{ET}_{\mathrm{A}}$ receptor antagonism in cardiovascular disease. Eur J Pharmacol 2014; 15: 210-213

9 Miyagawa K, Emoto N. Current state of endothelin receptor antagonism in hypertension and pulmonary hypertension. Ther Adv Cardiovasc Dis 2014; 8: 202-216

10 Novo G, Sansone A, Rizzo M, Guarneri FP, Pernice C, Novo S. High plasma levels of endothelin- 1 enhance the predictive value of preclinical atherosclerosis for future cerebrovascular and cardiovascular events: a 20year prospective study. J Cardiovasc Med (Hagerstown) 2014; 15: 696701

11 Wijesekara I, Kim SK. Angiotensin-I-converting enzyme (ACE) inhibitors from marine resources: prospects in the pharmaceutical industry. Mar Drugs 2010; 18: 1080-1093

12 Gulavita NK, Wright AE, McCarthy PJ, Pomponi SA, Kelly-Borges M, Chin $M$, Sills MA. Isolation and structure elucidation of 34-sulfatobastadin 13, an inhibitor of the endothelin A receptor, from a marine sponge of the genus Ianthella. J Nat Prod 1993; 56: 1613-1617

13 Pairet L, Wrigley SK, Chetland I, Reynolds EE, Hayes MA, Holloway J, Ainsworth AM, Katzer W, Cheng XM, Hupe DJ. Azaphilones with endothelin receptor binding activity produced by Penicillium sclerotiorum: taxonomy, fermentation, isolation, structure elucidation and biological activity. J Antibiot (Tokyo) 1995; 48: 913-923

14 Caballero-George C, Sorkalla T, Jakobs D, Bolaños J, Raja H, Shearer C, Bermingham E, Häberlein $H$. Fluorescence correlation spectroscopy in drug discovery: study of Alexa532-endothelin 1 binding to the endothelin $\mathrm{ET}_{\mathrm{A}}$ receptor to describe the pharmacological profile of natural products. Sci World J 2012; 2012: 524169

15 Caballero-George C. Does nature has the cure for hypertension?: Endothelin Receptors as Drug Targets. Curr Trends Biotechnol Pharm 2011; 5: $1251-1272$

16 Yanagisawa M, Kurihara H, Kimura S, Tomobe Y, Kobayashi M, Mitsui Y, Yazaki Y, Goto K, Masaki T. A novel potent vasoconstrictor peptide produced by vascular endothelial cells. Nature 1988; 332: 411-415

17 Simonson MS, Dunn MJ. Cellular signaling by peptides of the endothelin gene family. FASEB J 1990; 4: 2989-3000

18 Rabelink TJ, Stroes ES, Bouter KP, Morrison P. Endothelin blockers and renal protection: a new strategy to prevent end-organ damage in cardiovascular disease. Cardiovasc Res 1998; 39: 543-549

19 Tirapelli CR, Fecteau MH, Honore JC, Legros E, Gobeil F, D'Orleans-Juste P. Enzymatic pathways involved in the generation of endothelin-1(1-31) from exogenous big endothelin- 1 in the rabbit aorta. Br J Pharmacol 2006; 148: 527-535

20 Casey ML, Word RA, MacDonald PC. Endothelin-1 gene expression and regulation of endothelin mRNA and protein biosynthesis in a vascular human amnion. Potential source of amniotic fluid endothelin. J Biol Chem 1991; 266: 5762-5768

21 Agapitov AV, Haynes WG. Role of endothelin in cardiovascular disease. J Renin Angiotensin Aldosterone Syst 2002; 3: 1-15

22 Holzhauser L, Zolty $R$. Endothelin receptor polymorphisms in the cardiovascular system: potential implications for therapy and screening. Heart Fail Rev 2014; 19: 743-758

23 Mazzuca MQ Khalil RA. Vascular endothelin receptor type B: structure, function and dysregulation in vascular disease. Biochem Pharmacol 2012; 84: 147-162 
24 Kirkby NS, Hadoke PW, Bagnall AJ, Webb DJ. The endothelin system as a therapeutic target in cardiovascular disease: great expectations or bleak house. Br J Pharmacol 2008; 153: 1105-1119

25 Moorhouse RC, Webb DJ, Kluth DC, Dhaun N. Endothelin antagonism and its role in the treatment of hypertension. Curr Hypertens Rep 2013; 15: 489-496

26 Gray GA, Webb $D$. The endothelin system and its potential as a therapeutic target in cardiovascular disease. Pharmacol Ther 1996; 72: 109-148

27 McMahon EG, Palomo MA, Moore WM. Phosphoramidon blocks the pressor activity of big endothelin[1-39] and lowers blood pressure in spontaneously hypertensive rats. J Cardiovasc Pharmacol 1991; 17: 29-33

28 Martínez-Miguel P, Medrano-Andrés D, Lopes-Martín V, Arribas-Gómez I, Rodríguez-Puyol M, Rodríguez-Puyol D, López-Ongil S. Regulation of endothelin-converting enzyme-1 (ECE-1) by the calcimimetic R-568. Pharmacol Res 2013; 76: 106-118

29 Habib GB, Basra SS. Are there any new pharmacologic therapies on the horizon to better treat hypertension: a state-of-the-art paper. J Cardiovasc Pharmacol Ther 2014; 19: 516-525

30 Strachan E, Spratt C, Wilkinson B, Johnston R, Gray G, Webb J. Systemic blockade of the endothelin-B receptor increases peripheral vascular resistance in healthy men. Hypertension 1999; 33: 581-585

31 Nakamura H, Kobayashi J, Kobayashi M, Ohizumi Y, Hirata Y. Xestoquinone. A novel cardiotonic marine natural product isolated from the Okinawan sea sponge Xestospongia sapra. Chem Letters 1985; 6: 713716

32 Zhu HB, Geng MY, Guan HS, Zhang JT. Antihypertensive effects of $D$ polymannuronic sulfate and its related mechanisms in renovascular hypertensive rats. Acta Pharmacol Sin 2000; 21: 727-732

33 Endo $M$, Nakagawa W, Hamamoto Y, Ishihama $M$. Pharmacologically active substances from southern pacific marine invertebrates. Pure Appl Chem 1986; 58: 387-394

34 Kaul PN. Biomedical potencial of the sea. Pure Appl Chem 1982; 54: 1963-1972

35 Anastasi A, Erspamer $V$. The isolation and amino acid sequence of eledoisin, the active endecapeptide of the posterior salivary glands of Eledone. Arch Biochem Biophys 1963; 101: 56-65

36 Ihara M, Fukuroda T, Saeki T, Nishikibe M, Kojiri K, Suda H, Yano M. An endothelin receptor $\left(\mathrm{ET}_{\mathrm{A}}\right)$ antagonist isolated from Streptomyces misakiensis. Biochem Biophys Res Commun 1991; 178: 132-137

37 Ihara M, Ishikawa K, Fukuroda T, Saeki T, Funabashi K, Fukami T, Suda H, Yano $M$. In vitro biological profile of a highly potent novel endothelin (ET) antagonist BQ-123 selective for the ETA receptor. J Cardiovasc Pharmacol 1992; 20 (Suppl. 12): S11-S14

38 Miyata S, Ohhata N, Murai H, Masui Y, Ezaki M, Takase S, Nishikawa M, Kiyoto S, Okuhara M, Kohsaka M. WS009 A and B, new endothelin receptor antagonists isolated from Streptomyces sp. No. 89009. I. Taxonomy, fermentation, isolation, physico-chemical properties and biological activities. J Antibiot (Tokyo) 1992; 45: 1029-1040

39 Takaishi S, Tuchiya N, Sato A, Negishi T, Takamatsu Y, Matsushita Y, Watanabe T, Iijima Y, Haruyama H, Kinoshita T, Tanaka M, Kodama K. B90063, a novel endothelin converting enzyme inhibitor isolated from a new marine bacterium, Blastobacter sp. SANK 71894. J Antibiot (Tokyo) 1998; 51: 805-815

40 Tsurumi Y, Fujie K, Nishikawa M, Kiyoto S, Okuhara M. Biological and pharmacological properties of highly selective new endothelin converting enzyme inhibitor WS79089B isolated from Streptosporangium roseum No. 79089. J Antibiot (Tokyo) 1995; 48: 169-174

41 Nakamura M, Ito Y, Ogawa K, Michisuji Y, Sato S, Takada M, Hayashi M, Yaginuma S, Yamamoto S. Stachybocins, novel endothelin receptor antagonists, produced by Stachybotrys sp. M6222. I. Taxonomy, fermentation, isolation and characterization. J Antibiot (Tokyo) 1995; 48: 13891395
42 Wu B, Oesker V, Wiese J, Malien S, Schmaljohann R, Imhoff JF. Spirocyclic drimanes from the marine fungus Stachybotrys sp. strain MF347. Mar Drugs 2014; 12: 1924-1938

43 Zhou H, Zhu T, Cai S, Gu Q Li D. Drimane sesquiterpenoids from the mangrove-derived fungus Aspergillus ustus. Chem Pharm Bull (Tokyo) 2011; 59: 762-766

44 Liu H, Edrada-Ebel R, Ebel R, Wang Y, Schulz B, Draeger S, Müller WE Wray $V$, Lin $W$, Proksch $P$. Drimane sesquiterpenoids from the fungus Aspergillus ustus isolated from the marine sponge Suberites domuncula. J Nat Prod 2009; 72: 1585-1588

45 Roggo BE, Petersen F, Sills M, Roesel JL, Moerker T, Peter HH. Novel spirodihydrobenzofuranlactams as antagonists of endothelin and as inhibitors of HIV-1 protease produced by Stachybotrys sp. I. Fermentation, isolation and biological activity. J Antibiot (Tokyo) 1996; 49: 13-19

46 Ogawa T, Ando K, Tanaka T, Uosaki Y, Matsuda Y. RES-1149-1 and - 2 novel non-peptidic endothelin type $B$ receptor antagonists produced by Aspergillus sp. I. Taxonomy of producing strain, fermentation, isolation, and physico-chemical and biological properties. J Antibiot (Tokyo) 1996; 49: 1-5

47 Hayes MA, Wrigley SK, Chetland I, Reynolds EE, Ainsworth AM, Renno DV, Latif MA, Cheng XM, Hupe DJ, Charlton P, Doherty AM. Novel drimane sesquiterpene esters from Aspergillus ustus var. pseudodeflectus with endothelin receptor binding activity. J Antibiot (Tokyo) 1996; 49: 505-512

48 Li J, Yang X, Lin Y, Yuan J, Lu Y, Zhu X, Li J, Li M, Lin Y, He J, Liu L. Meroterpenes and azaphilones from marine mangrove endophytic fungus Penicillium 303\#. Fitoterapia 2014; 97: 241-246

49 Yamada T, Jinno M, Kikuchi T, Kajimoto T, Numata A, Tanaka R. Three new azaphilones produced by a marine fish-derived Chaetomium globosum. J Antibiot (Tokyo) 2012; 65: 413-417

50 Gao SS, Li XM, Zhang Y, Li CS, Cui CM, Wang BG. Comazaphilones A-F, azaphilone derivatives from the marine sediment-derived fungus Penicillium commune QSD-17. J Nat Prod 2011; 74: 256-261

51 Ogawa T, Ando K, Aotani Y, Shinoda K, Tanaka T, Tsukuda E, Yoshida M, Matsuda Y. RES-1214-1 and -2, novel non-peptidic endothelin type A receptor antagonists produced by Pestalotiopsis sp. J Antibiot (Tokyo) 1995; 48: 1401-1406

52 Proksch P, Ebel R, Edrada RA, Wray V, Steube K. Bioactive natural products from marine invertebrates and associated fungi. Prog Mol Subcell Biol 2003; 37: 117-142

53 Patil A, Freyer A, Breen A, Carte B, Johnson R. Halistanol disulfate B, a novel sulfate sterol from sponge Pachastrella sp.: inhibitor of endothelin converting enzyme. J Nat Prod 1996; 59: 606-608

54 Gershenzon J, Dudareva $N$. The function of terpene natural products in the natural world. Nat Chem Biol 2007; 3: 408-414

55 Latek D, Modzelewska A, Trzaskowski B, Palczewski K, Filipek S. G protein-coupled receptors-recent advances. Acta Biochim Pol 2012; 59: 515-529

56 Pin JP, Galvez T, Prézeau L. Evolution, structure, and activation mechanism of family $3 / C$ G-protein-coupled receptors. Pharmacol Ther 2003; 98: 325-354

57 Senni K, Pereira J, Gueniche F, Delbarre-Ladrat C, Sinquin C, Ratiskol J, Godeau G, Fischer AM, Helley D, Colliec-Jouault S. Marine polysaccharides: a source of bioactive molecules for cell therapy and tissue engineering. Mar Drugs 2011; 9: 1664-1681

58 Conibear AC, Craik DJ. The chemistry and biology of theta defensins. Angew Chem Int Ed Engl 2014; 53: 10612-10623

59 Sjögren M, Jonsson PR, Dahlström M, Lundälv T, Burman R, Göransson U, Bohlin $L$. Two brominated cyclic dipeptides released by the coldwater marine sponge Geodia barretti act in synergy as chemical defense. J Nat Prod 2011; 74: 449-454

60 Xiong Z, Wang J, Hao J, Wang Y. Recent advances in the discovery and development of marine microbial natural products. Mar Drugs 2013; 11: $700-717$ 